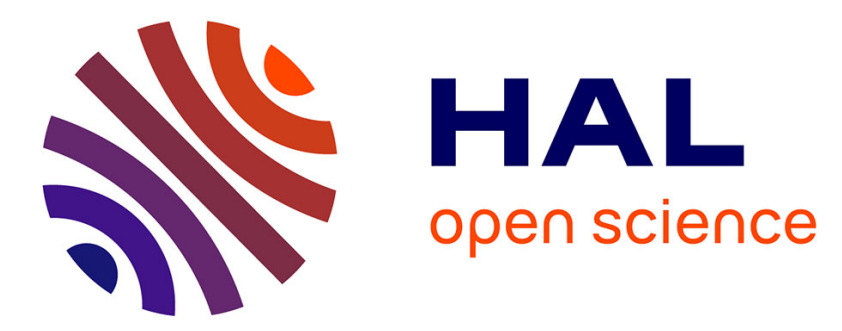

\title{
First diatomyid rodent from the Early Miocene of Arabia
}

\author{
Raquel López-Antoñanzas
}

\section{To cite this version:}

Raquel López-Antoñanzas. First diatomyid rodent from the Early Miocene of Arabia. The Science of Nature Naturwissenschaften, 2011, 98 (2), pp.117 - 123. 10.1007/s00114-010-0745-0 . hal-01920853

\section{HAL Id: hal-01920853 https://hal.science/hal-01920853}

Submitted on 17 Dec 2020

HAL is a multi-disciplinary open access archive for the deposit and dissemination of scientific research documents, whether they are published or not. The documents may come from teaching and research institutions in France or abroad, or from public or private research centers.
L'archive ouverte pluridisciplinaire HAL, est destinée au dépôt et à la diffusion de documents scientifiques de niveau recherche, publiés ou non, émanant des établissements d'enseignement et de recherche français ou étrangers, des laboratoires publics ou privés. 


\section{First diatomyid rodent from the Early Miocene of Arabia}

\section{Raquel López-Antoñanzas}

5

Departamento de Paleobiología, Museo nacional de Ciencias naturales-CSIC, c/ José Gutiérrez Abascal 2 ,

Madrid 28006, Spain.

Corresponding author: Fax: +34 915645078 .

E-mail address: ralopan@mncn.csic.es 
20 Abstract The Asian family Diatomyidae is known from the Early Oligocene to the present. Among living rodents, this group comprises only the recently discovered Laonastes aenigmamus from Laos. Fossil diatomyids are known from only a few sites in which they are often rare. The discovery of Pierremus explorator gen. nov. sp. nov. in the Lower Miocene of As-Sarrar (Saudi Arabia) raises to ten the number of extinct

25 diatomyid species recognized. $P$. explorator is the first record of a diatomyid from the Afro-Arabian plate. This discovery provides evidence that, together with other rodents (ctenodactylids, zapodids...), the diatomyids took advantage of the corridor that was established between Afro-Arabia and Eurasia in Early Miocene times.

30 Keywords Diatomyidae Saudi Arabia Miocene Dam Formation Paleobiogeography 


\section{Introduction}

The Diatomyidae Mein and Ginsburg 1997 is a family of hystricomorphous and sciurognathous rodents that originated from the Paleogene ctenodactyloid stock (Flynn 2007; Dawson et al. 2006; Marivaux et al. 2004b). As presently understood, they comprise 9 fossil species in 4 genera (Fallomus razae Flynn, Jacobs and Cheema 1986, “F.” ladakhenis Nanda and Sahni 1998, F. ginsburgi Marivaux and Welcomme 2003, F. quraishyi Marivaux and Welcomme 2003, Diatomys shantungensis Li 1974, D. liensis Mein and Ginsburg 1985, D. chitaparwalensis Flynn 2006, Marymus dalanae Flynn 2007, Willmus maximus Flynn and Morgan 2005). The amazing discovery in 2005 of the modern Laonastes aenigmamus Jenkins, Kilpatrick, Robinson and Timmins

452005 was recognized as a member of the family Diatomyidae by Dawson et al. (2006).

The Diatomyidae are usually uncommon in the fossil record. They are known from the Early Oligocene to the late Miocene in Pakistan (Flynn 2006, 2007; Flynn and Morgan 2005; Flynn et al. 1986; Marivaux and Welcomme 2003), India (Nanda and Shani 1998), Thailand (Ducrocq et al. 1995, Marivaux et al. 2004a, Mein and

50 Ginsbourg 1985, 1997), China (Ducrocq et al. 1995; Li 1974) and Japan (Kato and Otsuka 1995) (Fig. 1). Diatomys sp. was also mentioned from the Lower Miocene of Jebel Zelten, Libya (Savage 1990). However, it is most likely a misidentification because all the remains collected at Jebel Zelten during the geological and paleontological field campaigns carried out by Fejfar in 1982-1983 and by El ArnautiDaams in 1997 were later studied in detail and no material of Diatomyidae was found amongst them (Wessels et al. 2003, 2008; Fejfar and Horáček 2006; Fejfar pers. comm. 2010). In this work, I report the first record of a diatomyid from the Afro-Arabian plate. 


\section{Geological Context}

The fossiliferous localities of the As-Sarrar region are located about $10 \mathrm{~km} \mathrm{N-NW}$ of As-Sarrar $\left(26^{\circ} 59^{\prime} \mathrm{N} ; 48^{\circ} 23^{\prime} \mathrm{E}\right)$, less than $90 \mathrm{~km}$ from the coast of the Arabian Gulf and about $250 \mathrm{~km} \mathrm{NW}$ of Al Hofuf (Thomas 1982; Thomas et al. 1982) (Fig. 2a).

70 Twenty sites numbered 4 to 9 and 11 to 24 are situated in the Dam Formation (Fig. 2b).

Only 4 of them have yielded rodent remains and among them only at locality 9 the family Diatomyidae is represented.

The Dam Formation in the As-Sarrar area displays interbedded continental and marine facies indicating the proximity of the seashore (Fig. 2c). Thus, during deposition of the Dam Formation, the area of As-Sarrar was a transitional zone, particularly sensitive to environmental changes (Thomas and Battail 1980).

All the vertebrate localities of the Dam Formation in the As-Sarrar area are considered roughly contemporaneous (Thomas et al. 1982). Thomas et al. (1982:132) and Thomas (1984:267-268) presented the negative and positive evidence for a late early Miocene age. The results of the study of some rodent families from As-Sarrar (López-Antoñanzas 2004, López-Antoñanzas and Sen 2004, 2005, 2006) are consistent with a late Early Miocene age for this site. 
Pierremus gen. nov.

85

Order Rodentia Bowdich, 1821

Family Diatomyidae Mein and Ginsburg, 1997

Genus Pierremus gen. nov.

90 Etymology Named after the great paleontologist Pierre Mein for his substantial contribution to the understanding of rodent evolution, plus mus (Latin for mouse).

Diagnosis Diatomyid rodents with a trilophodont pattern on the lower teeth; characterized by protruding cusps and cuspids; having strong to indistinct ectostylid and

95 lacking accessory styles or stylids; lower teeth with the entoconid anteriorly displaced with respect to the hypoconid and with a prominent development of the hypoconulid; the third lower molar being the largest of the cheek teeth.

Differential diagnosis Differs from Fallomus, Diatomys, Marymus, Willmus and

100 Laonastes in having a trilophodont pattern on the lower teeth, the entoconid anteriorly displaced with respect to the hypoconid and the $\mathrm{m} 3$ much larger than the $\mathrm{m} 1$ and the $\mathrm{m} 2$. 
Type species Pierremus ladakhensis (Nanda and Sahni 1996) (Fig. 3a)

105

Referred species Pierremus explorator sp. nov. (Fig. 3b)

Pierremus ladakhensis (Nanda and Sahni 1996) (Fig. 3a)

Synonymy

110 Fallomus ladakhensis Nanda and Sahni, 1996

Fallomus razae (partim) Flynn, Jacobs and Cheema, 1986

Referred material WIMF/A 1701-1703, WIMF/A 1705 (Kargil area, India; Nanda and Sahni, 1996) and SHM-CP 353, SHM-CP 250, TF 6181-6182 (Phetchaburi Province, Thailand; Marivaux et al., 2004a)

Nanda and Sahni (1998) erected the new species Fallomus ladakhensis on the basis of two isolated teeth (second and third lower molars) from the Oligo-Miocene Kargil Formation of the Ladakh Molasse Group of the Kargil area (India). In the same work, these authors described from the same locality five isolated teeth that they identified as F. razae: one first lower molar (WIMF/A 1701), three second lower molars (WIMF/A 1702-1704) and one upper molar (WIMF/A 1705). However, these teeth are larger and high crowned and have a quite different morphology from the material from the Bugti area (e.g., they have a trilophodont dental pattern, the entoconid is more anteriorly located than the hypoconid) for them to be considered to belong to $F$. razae. In fact, all the specimens but WIMF/A 1704, which is smaller (but still too large to pertain to $F$. 
razae), could belong to $F$. ladakhensis. In addition, F. ladakhensis (Fig. 3a) does not match the diagnosis given by Flynn et al. (1986) for the genus Fallomus in having higher crowned teeth, a trilophodont dental pattern, the entoconid anteriorly displaced with respect to the hypoconid and the third lower molar larger than the second one. Additional material of Pierremus ladakhensis comes from the late Oligocene deposits of the Nong Ya Plong coal mine, which is located in peninsular Thailand (Phetchaburi Province; Marivaux et al. 2004a). The material of the former Fallomus ladakhensis has been described in details by Nanda and Sahni (1996) and Marivaux et al. (2004a)

\section{Pierremus explorator sp. nov.}

Etymology Explorator, Latin for explorer, for being the first known diatomyid that "dared" to travel out of the Eurasian plate.

Holotype MNHN-AS9-22 (Fig. 3), a right p4, the single specimen found to date. It is housed in the palaeontological collections of the Museum national d'Histoire naturelle (Paris, France).

Locality, Horizon and Age The single specimen of Pierremus explorator has been recorded from the late early Miocene locality 9 of the As-Sarrar area (Saudi Arabia).

Diagnosis Diatomyid rodent with brachydont dentition; having a trilophodont dental pattern with large cuspids; the metaconid anteriorly located, the protoconid posteriorly 
displaced with respect to the metaconid, the entoconid much anteriorly displaced with regard to the hypoconid, and lacking accessory stylids.

Differential diagnosis MNHN-AS9-22 differs from the $\mathrm{p} 4$ of all species belonging to the family Diatomyidae (except for Pierremus ladakhensis) in having a trilophodont dental pattern and the entoconid anteriorly displaced with respect to the hypoconid. It differs from $P$. ladakhensis in being more brachydont, smaller, in having a large hypoconid and in lacking the anteroconid. This species is smaller than Fallomus quraishyi, Diatomys liensis, D. shantungensis, Marymus dalanae, Willmus maximus and the extant Laonastes aenigmamus.

\section{Description}

The holotype is a worn brachydont permanent premolar (AS9-22:1.661 x $1.241 \mathrm{~mm}$ ) with the trigonid slightly narrower than the talonid. Its occlusal outline is oval, longer than wide. This tooth is identified as a permanent premolar rather than a deciduous one mainly due to the lack of anteroconid and the presence of massive main cuspids. The presence of the anteroconid and sharp principal cuspids and crests are indeed usually characteristics of milk teeth (Hartenberger 1982:23; Marivaux and Welcomme 2003:422). MNHN-AS-9-22 has an anterocingulid and it is characterized by a trilophodont dental pattern with large metaconid, protoconid, entoconid, hypoconid and hypoconulid. The metaconid is located on the anterolingual border of the tooth. There is 
isolated and it is located much further back than the metaconid. Both metalophulid I and metalophulid II (anterior and posterior arms of the protoconid, respectively) are absent. The entoconid is much more anteriorly positioned than the hypoconid. The tooth is damaged in its posterobuccal side and therefore it is not possible to know if it had the 175 ectostylid, but additional stylids are absent. A longitudinal valley between the buccal (protoconid) and lingual (metaconid) cuspids runs posterobuccally. The anterior side of the hypoconid and the entoconid are linked by the hypolophid. The enlarged hypoconulid forms a third posterior lophid by contact with the hypoconid.

180 Discussion

\section{Fallomus}

The genus Fallomus was originally interpreted as a Chapattimyidae incertae sedis

185 (Flynn et al. 1986). After the works of Flynn et al. (1986) and Mein and Ginsburg (1997), it has been included in the Diatomyidae (Marivaux and Welcomme 2003; Marivaux et al. 2002, 2004a). Flynn et al. (1986) characterized the genus as follows: cheek teeth transversely bilophodont, lacking well-developed longitudinal crests, high, inclined cusps; upper cheek teeth with four major cusps, lacking metaconule and 190 paraconule; lower teeth with five major cusps including hypoconulid; enterostyle and ectostylid present in high frequency; with the second molars being the largest cheek teeth of the tooth row; four-rooted M1-M3 and m2. These authors named the type and only species known then Fallomus razae on the basis of a large sample of specimens 
from locality Y417 (south of Dera Bugti, Balochistan, Pakistan). An early Oligocene

age is currently assigned to the site (Welcomme et al., 2001; Marivaux and Welcomme 2003; Métais et al., 2009).

Marivaux and Welcomme (2003) named two new species of Fallomus (F. quraishyi and $F$. ginsburgi) on the basis of numerous specimens from the early Oligocene Paali Nala C2 locality of the Chitarwata Formation (Bugti Hills, Balochistan, Pakistan) (Figs. 3D-E). From the same locality, remains of F. razae (Fig. 3c) were found (Marivaux and Welcomme 2003). Thus, three species belonging to the genus Fallomus are known to date: F. razae, $F$. quraishyi and $F$. ginsburgi (Figs. 3C-E).

Additional material of Fallomus razae has been found from the late Oligocene Zinda Pir Dome localities Z144 and Z108 (Flynn 2006). In this latter locality, F. razae was recorded along with $F$. quraishyi and $F$. ginsburgi.

\section{Pierremus}

As seen above, the new genus Pierremus is here named to include the former Fallomus

210 ladahkensis, which did not match the diagnosis of the genus Fallomus proposed by Flynn et al. (1986). The new species from Saudi Arabia, P. explorator, shares with $P$. ladakhensis the following synapomorphies: a trilophodont dental pattern and the entoconid anteriorly displaced with respect to the hypoconid. These two species form a clade with sister-group relationships with Fallomus (Fig.4 and supporting online 215 material). 
Fallomus and Pierremus share some characters with primitive chapattimyid

ctenodactyloids such as the presence of large submolariform premolars, large third molars, and the retention of the hypoconulid on the lower molars. However, the genus Pierremus is more derived than Fallomus in having a trilophodont dental pattern and in 220 having the entoconid anteriorly displaced.

The single specimen of Pierremus explorator has retained another primitive ctenodactyloid feature: the presence of an anterocingulid, which is absent in $P$. ladakhensis. Thus, $P$. explorator may be more primitive than $P$. ladakhensis. Furthermore, regarding the size and height of the crown, P. ladakhensis appears more derived than P. explorator and Fallomus. In fact, the former species is much larger and has higher crowned molars than the latter taxa. These characters, together with a more derived incisor enamel microstructure, have been thought to mean that $P$. ladakhensis is more advanced morphologically than Fallomus (Marivaux et al. 2004a).

Regarding the pattern of premolar replacement, the three species of Fallomus known 230 to date show the primitive ctenodactyloid condition of normal premolar replacement.

The deciduous premolars of Fallomus (the most ancient genus of the diatomyid rodents) are easily recognizable, even though they have not a very different morphology from that of the permanent premolars (Marivaux and Welcomme 2003; Flynn 2007).

This is not the case for more modern genera. With regard to the pattern of premolar 235 replacement in Pierremus, little can be state with certainty. The only known two premolars of Pierremus ladhakensis are insufficient to settle the question. It is worth mentioning that the only two specimens of p4 of P. ladakhensis found (Marivaux et al. 2004a) have a developed anteroconid. According to Marivaux and Welcomme (2003), the deciduous premolars of Fallomus are distinguishable from the permanent ones 
240 thanks to the development of anteroconids and anterocones, a suggestion with which I agree. This could suggest that the two lower premolars of $P$. ladakhensis are deciduous premolars. However, the two mandibles of P. ladakhensis (SHM-CP 250 and SHM-CP 353) from Thailand do not appear to correspond to juvenile individuals (the third molar is fully erupted and worn). Furthermore, the careful examination of this material did not 245 show any trace of erupting permanent premolars (Marivaux pers. comm. 2010). Thus, it is possible that $P$. ladakhensis retained the deciduous premolars throughout its lifetime as was the case of Diatomys (Mein and Ginsburg 1997), probably that of Marymus (Flynn, 2007), both of which also show an anteroconid on the premolars, and that of the extant Laonastes (Hautier and Saksiri, 2009). If so, P. ladakhensis would be derived

250 with respect to Fallomus also in the lack of premolar replacement. The discovery of additional material of $P$. ladakhensis is necessary in order to confirm or refute this hypothesis. On the other hand, the finding of a single premolar of the Arabian species does not allow inferring the pattern of premolar replacement in P. explorator.

\section{Conclusion}

The new diatomyid species found at the late early Miocene locality 9 of As-Sarrar belongs to a new genus, Pierremus, to which is reallocated Fallomus ladakhensis. The latter species does not belong to the genus Fallomus because of the trilophodont dental

260 pattern of its lower cheek teeth and the entoconid anteriorly displaced with respect to the hypoconid. These characters are shared with the new Arabian species, P. explorator, and suggest that Pierremus is more derived than Fallomus. In addition, P. ladakhensis is more derived than P. explorator and Fallomus spp. in being larger and in having 
higher crowned teeth. Furthermore, $P$. ladakhensis is more derived than Fallomus spp.

265 in the incisor enamel microstructure and, perhaps, in suppressing the permanent premolars, which is a derived condition among the members of this family. Laonastes, the sole extant member of the Diatomyidae, is also characterized by the retention of the deciduous premolars (Hautier and Saksiri, 2009). If the recovery of more material of Pierremus confirms that it lacked premolar replacement, the acquisition of this derived condition within the family Diatomyidae would have occurred during the Late Oligocene.

Except for the early Oligocene Paali Nala locality (Pakistan) and the Middle Miocene Li Basin (Thailand), the diatomyids are rare in the fossil record so that each find has significance for the understanding of their evolution, which, for the time being, 275 is quite enigmatic. It has been postulated that about 18.5 million years ago, the counterclockwise rotation of the Afro-Arabian plate brought it into contact with Eurasia, from which it was formerly separated by the Tethys Seaway (e.g., Rögl 1998, 1999a, 1999b). The obstruction of the Tethys and the establishment of passageways between the two land masses enabled continental faunal interchanges between the Afro-Arabian and

280 Anatolian areas. The existence of these corridors has been substantiated by the fossil record of various mammalian groups including rodents (e.g. Koufos et al. 2005; LópezAntoñanzas 2004; Wessels 2009). By the beginning of the Miocene the emerged lands of the Arabian plate experienced the arrival of rodents from various origins. Previous works on the Early Miocene rodents from As-Sarrar (López-Antoñanzas 2004, López-

285 Antoñanzas and Sen 2004, 2005, 2006) provided us with examples of long distance dispersal from Asia, as evidenced by the ctenodactylid Sayimys assarrarenis and the zapodid Arabosminthus isabellae. Pierremus explorator, a rodent with incontestable Asian origin, proves that diatomyids also took advantage of this corridor. The dispersal 
of ctenodactylids and zapodids from Asia to North Africa (Fejfar and Horáček 2006;

290 Wessels 2009; Wessels et al. 2003, 2008) through the Arabian Peninsula suggests that the absence of diatomyid remains in Africa could be due to a bias in the Early Miocene fossil record of this continent.

Acknowledgments The rodent remains from Saudi Arabia were collected during field

295 campaigns organized by H. Thomas (Collège de France, Paris) with permission of the Department of Antiquities and Museums in Riyadh. S. Sen (Muséum national d'Histoire naturelle, Paris) kindly lent the specimen for study. The author thanks M. A. ÁlvarezSierra (Universidad Complutense, Madrid), R. Asher (University of Cambridge, Cambridge), L. Flynn (Harvard University, Cambridge), L. Marivaux (Université Montpellier II, Montpellier), P. Mein (Université Lyon I, Villeurbanne), P. PeláezCampomanes (Museo nacional de Ciencias naturales-CSIC, Madrid) and the anonymous reviewers who helped to improve this work. Thanks are due to M. Pickford (Collège de France, Paris) for correcting the English of the manuscript.

The author is currently supported by the Ramón y Cajal Program and the research project CGL2008-05813-CO2-01 directed by J. Morales (Museo nacional de Ciencias naturales-CSIC, Madrid).

\section{References}


Ducrocq S, Chaimanee Y, Suteethorn V, Jaeger JJ (1995) Mammalian faunas and the ages of the continental Tertiary fossiliferous localities from Thailand. J Southeast Asian Earth Sci 12: 65-78

Fejfar O, Horáček I (2006) The Early Miocene mammalian assemblages in Jebel Zelten, Libya. Lynx n. s. 37: 95-105

Flynn LJ (2000) The great small mammal revolution. Himalayan Geol 21: 39-42

Flynn LJ (2006) Evolution of the Diatomyidae, an endemic family of Asian rodents. Vert PalAsiat 44: 182-192

Flynn LJ (2007) Origin and evolution of the Diatomyidae, with clues to their paleoecology from the fossil record. Bull Carnegie Mus Nat Hist 39: 173-181

Flynn LJ, Jacobs LL, Cheema IU (1986) Baluchimyinae, a new ctenodactyloid rodent subfamily from the Miocene of Baluchistan. Amer Mus Novitates 2841: 1-58

Flynn LJ, Morgan ME (2005) An unusual diatomyid rodent from an infrequently sampled Late Miocene interval in the Siwaliks of Pakistan. Palaeontol Electron 8 (1): 17A p 10

Hartenberger JL (1982) A review of the Eocene rodents of Pakistan. Contrib Mus Paleontol Univ Michigan 26: 19-35

Jenkins PD, Kilpatrick CW, Robinson MF, Timmins RJ (2005) Morphological and molecular investigations of a new family, genus and species of rodent (Mammalia: Rodentia: Hystricognatha) from Lao PDR. Syst Biodivers 2: 410-454

330

Kato T, Otsuka H (1995) Discovery of the Oligo-Miocene rodents from west Japan and their geological and paleontological significance. Vert PalAsiat 33: 315-329

Koufos GD, Kostopoulos DS, Vlachou D (2005) Neogene/Quaternary mammalian migrations in Eastern Mediterranean. Belgian J Zool 135: 181-190

Hautier L, Saksiri S (2009). Masticatory muscle architecture in the Laotian rock rat Laonastes 335 aenigmamus (Mammalia, Rodentia): new insights into the evolution of hystricognathy. $\mathrm{J}$ Anat 215 : 401-410

Li CK (1974) A probable geomyoid rodent from Middle Miocene of Linchu, Shantung. Vert PalAsiat 12: 43-53 
López-Antoñanzas R (2004) Neogene Ctenodactylidae, Thryonomyidae, and Zapodidae (Rodentia) from 340 the Middle East: systematics, phylogeny, biostratigraphy, palaeogeography, and palaeoecology. Doctoral Thesis. Muséum national d'Histoire naturelle, Paris, p 323

López-Antoñanzas R, Sen S (2004) Ctenodactylids from the Lower and Middle Miocene of Saudi Arabia. Palaeontology 47: 1477-1494

López-Antoñanzas R, Sen S (2005) New species of Paraphiomys (Rodentia, Thryonomyidae) from the Lower Miocene of As-Sarrar, Saudi Arabia. Palaeontology 48: 223-233

López-Antoñanzas R, Sen S (2006) New Saudi Arabian Miocene jumping mouse (Zapodidae): Systematics and phylogeny. J Vert Paleontol 26: 170-181

Marivaux L, Chaimanee Y, Yamee C, Srisuk P, Jaeger JJ (2004a) Discovery of Fallomus ladakhensis Nanda \& Sahni, 1998 (Mammalia, Rodentia, Diatomyidae) in the lignites of Nong Ya Plong 350 (Phetchaburi Province, Thailand): Systematic, biochronological and paleoenvironmental implications. Geodiversitas 26: 493-507

Marivaux L, Vianey-Liaud M, Jaeger JJ (2004b) High-level phylogeny of early Tertiary rodents: dental evidence. Zool J Linn Soc 142: 105-134

Marivaux L, Welcomme JL (2003) New diatomyid and baluchimyine rodents from the Oligocene of Pakistan (Bugti Hills, Balochistan): Systematic and paleobiogeographic implications. J Vert Paleontol 23: 420-434.

Mein P, Ginsburg L (1985) Les rongeurs miocènes de Li (Thaïlande). C R Acad Sci, Sér II 301: 13691374

Mein P, Ginsburg L (1997) Les mammifères du gisement miocène inférieur de Li Mae Long, Thaïlande: systematique, biostratigraphie et paléoenvironnement. Geodiversitas 19: 783-844

Métais G, Antoine PO, Baqri SRH, Crochet JY, de Franceschi D, Marivaux L, Welcomme JL (2009) Lithofacies, Depositional Environments, Regional Biostratigraphy and Age of the Chitarwata Formation in the Bugti Hills, Balochistan, Pakistan. J Asian Earth Sci 34: 154-167

Nanda AC, Sahni A (1998) Ctenodactyloid rodent assemblage from Kargil Formation, Ladakh molasses group: Age and paleobiogeographic implications for the Indian subcontinent in the Oligo-Miocene. Geobios 31: 533-544

Rögl F (1998) Palaeogeographic considerations for Mediterranean and Parathetys Seaways (Oligocene to Miocene). Ann Naturhist Mus Wien 99A: 279-310 
Rögl F (1999a) Circum-Mediterranean Miocene Paleogeography. In: Rössner GH, Heissig K (eds) The 370 Miocene land mammals of Europe. Dr. Friedrich Pfeil, München, pp 39-48

Rögl F (1999b) Mediterranean and Paratethys Paleogeography during the Oligocene and Miocene. In:

Agustí J, Rook L, Andrews P (eds) The evolution of Neogene Terrestrial Ecosystems in Europe, vol.

1. Cambridge University Press, Cambridge, pp 8-22

Savage RJG (1990) The African Dimension in European Early Miocene Mammal Faunas. In: Lindsay E, 375

H, Falhbusch V, Mein P (eds), European Neogene Mammal Chronology. Plenum Press, New York, $587-599$

Thomas H (1982) La péninsule Arabique et l'expansion des Primates hominoïdes miocènes. In:

Montanaro Gallitelli E (ed), Essential of Historical Geology. Modena Press, Venice, 215-227

Thomas H (1984) Les Bovidae (Artiodactyla: Mammalia) du Miocène du sous-continent indien, de la

péninsule arabique et de l'Afrique : biostratigraphie, biogéographie et écologie. Palaeogeogr

Palaeoclimatol Palaeoecol 45: 251-299

Thomas H, Battail B (1980) Paleoenvironment in the Saudi Arabian lower Miocene (Eastern Province).

Unpublished report on Eastern Province Paleontological Survey, 10 pp.

Thomas H, Sen S, Khan M, Battail B, Ligabue G (1982) The Lower Miocene Fauna of As-Sarrar (Eastern province, Saudi Arabia). Atlal 5: 109-136

Welcomme JL, Benammi M, Crochet JY, Marivaux L, Métais G., Antoine PO Baloch I (2001)

Himalayan Forelands: paleontological evidence for Oligocene detrital deposits in the Bugti Hills (Balochistan, Pakistan). Geol Mag 138: 397-405.Wessels W (2009) Miocene rodent evolution and migration. Muroidea from Pakistan, Turkey and Northern Africa. Geol Ultraiectina 307: 1-290

390 Wessels W, Fejfar O, Peláez-Campomanes P, de Bruijn H (2003) Miocene small mammals from Jebel Zelten, Libya. Coloq Paleontol vol extra: 699-715

Wessels W, Fejfar O, Peláez-Campomanes P, van Der Meulen A, de Bruijn H, El-Arnauti A (2008) The age of the small mammal faunas from Jabal Zaltan, Libya. Garyounis Sci Bull spec iss 5: 129-138 
Fig. 1 Distribution of fossil and recent Diatomyidae localities. 1 As-Sarrar (Saudi Arabia). 2 Bugti (Pakistan). 3 Zinda Pir Dome (Pakistan). 4 Banda Daud Shah (Pakistan). 5 Potwar Plateau (Pakistan). 6 Ladakh (India). 7 Shanwang (Shandong 400 Province, China). 8 Xiacaowan (Jiangsu Province, China). 9 Kyushu (Japan). 10 Phetchaburi (Thailand). 11 Li Basin (Thailand). 12 Kammouhan (Laos).

Fig. 2 a Location of As-Sarrar in the Eastern Province of Saudi Arabia. b Detail of the surveyed area near the city of As-Sarrar with the location of the fossiliferous localities. c Stratigraphical section of locality 9. Data after Thomas et al. (1982).

Fig. 3 Diatomyid dental terminology used in this paper. a Pierremus ladakhensis, right mandible with p4-m1. b Pierremus explorator sp. nov., right p4. c Fallomus razae, right p4. d Fallomus ginsburgi, right p4. e Fallomus quraishyi, right p4. Scale bar equals 1 $\mathrm{mm}$.

410 Fig. 4 Single most parsimonious tree generated by the cladistic analysis performed in this paper (matrix in supplementary data). Bremer and relative Bremer support indices (Goloboff and Farris, 2001) of each clade are indicated at the appropriate. The tree has a length of 15 steps and a low level of homoplasy $(\mathrm{CI}=0.867$ and $\mathrm{RI}=0.833)$ 


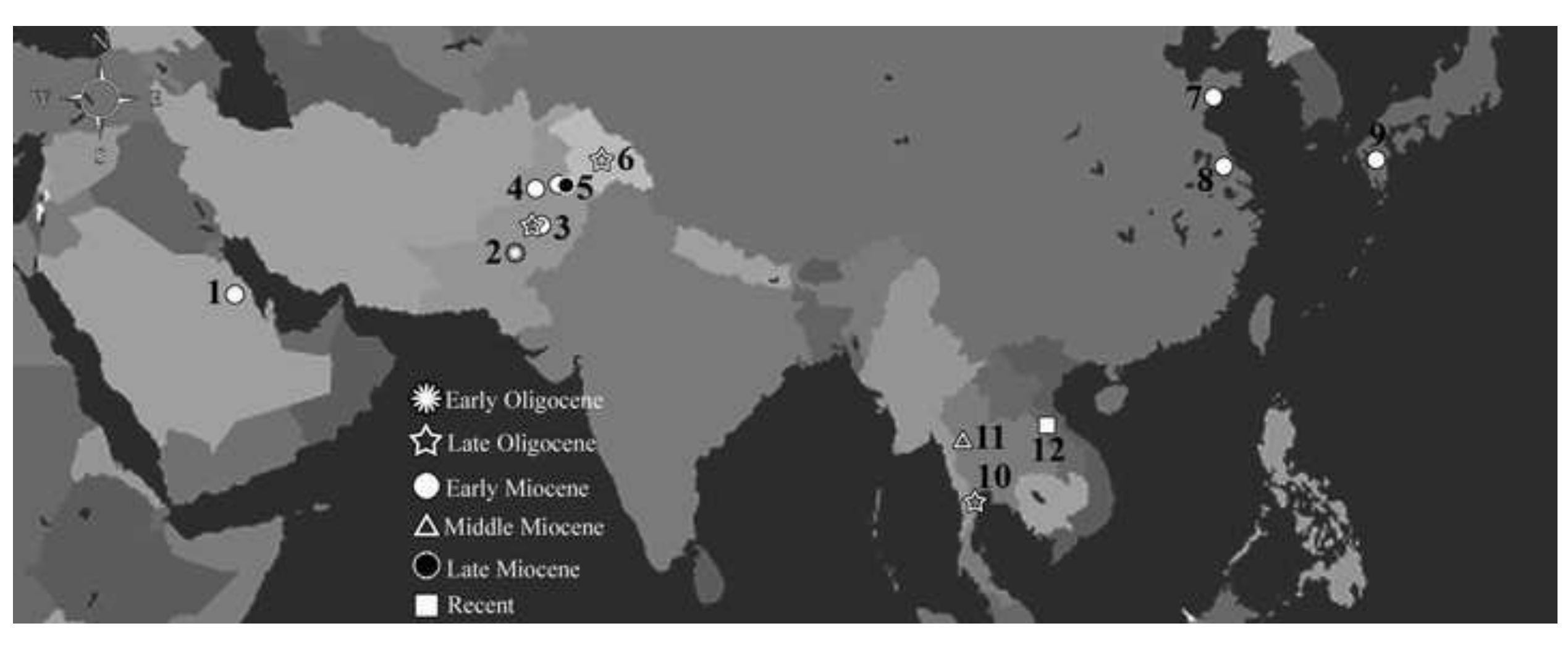




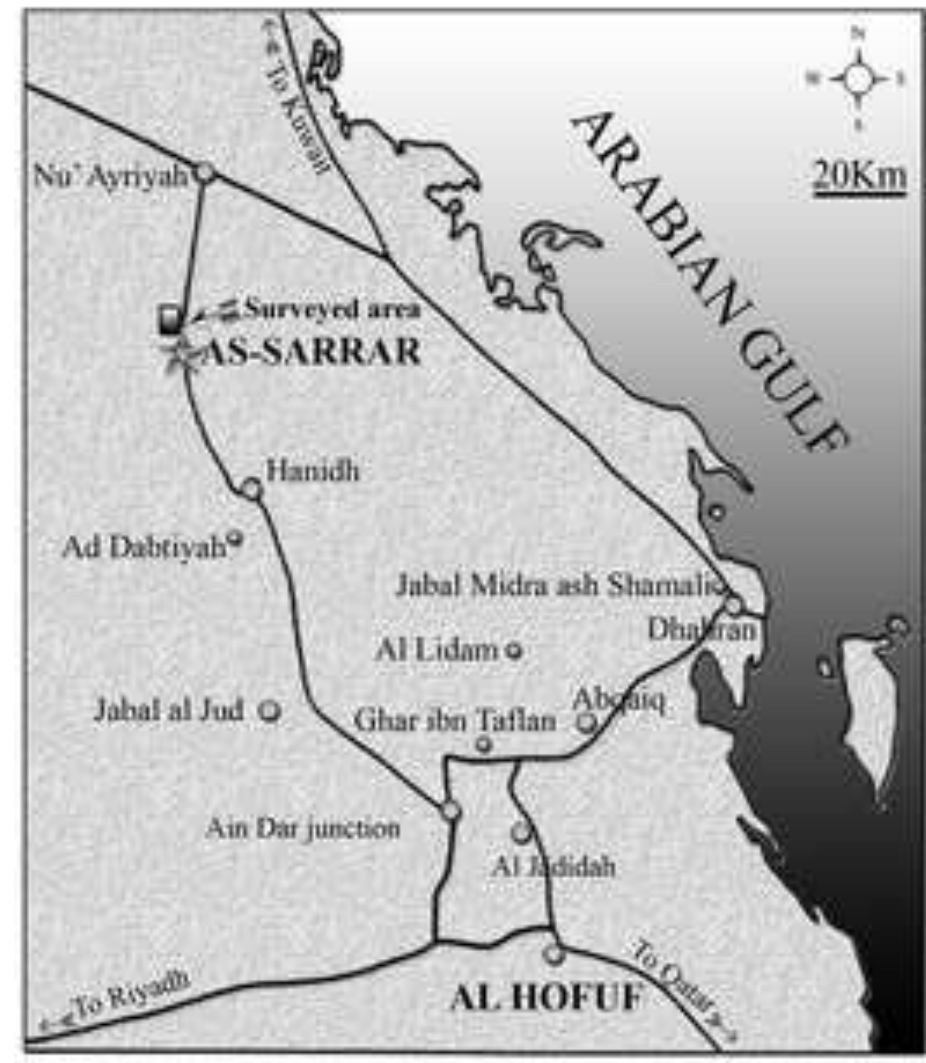

A

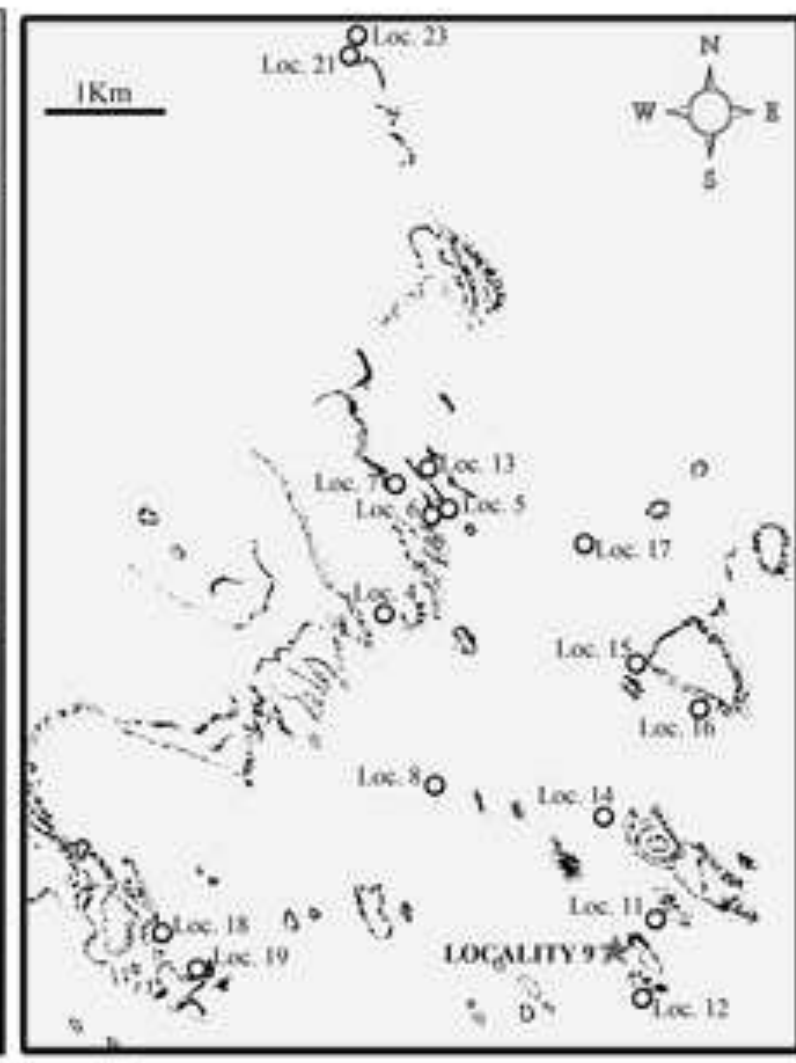

B

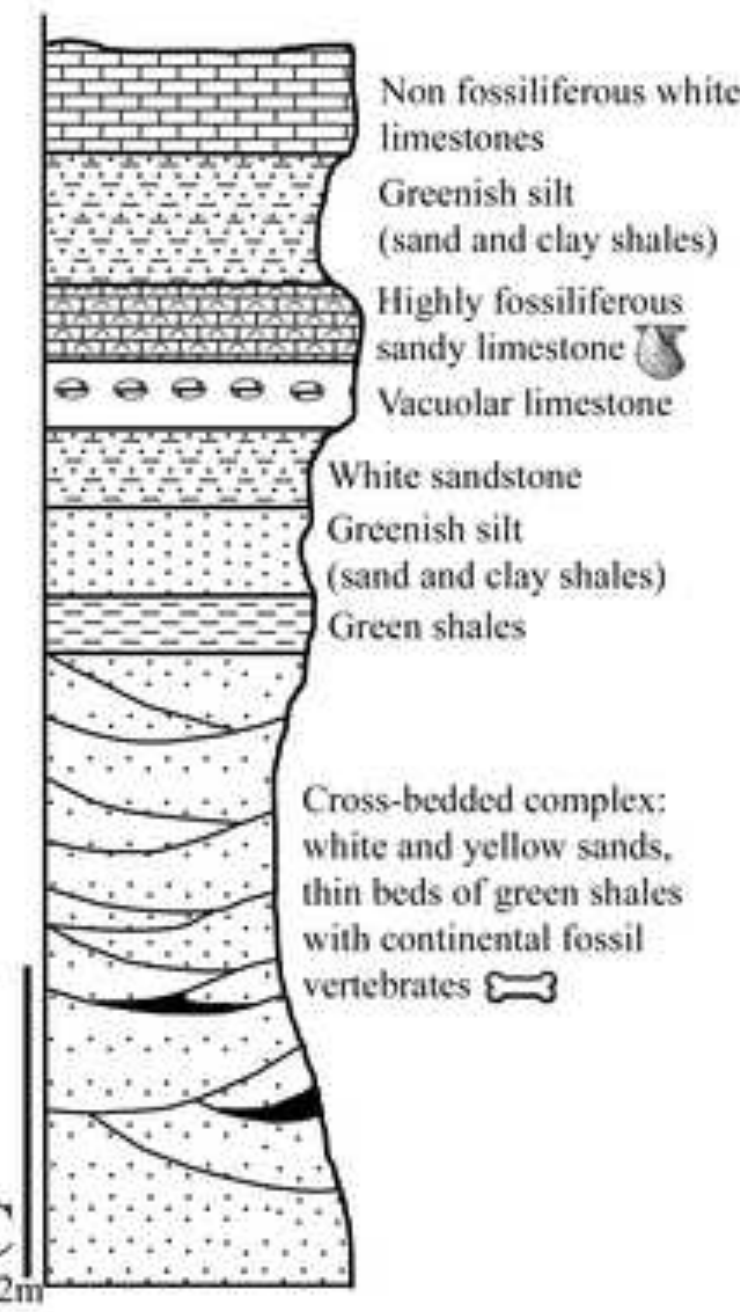




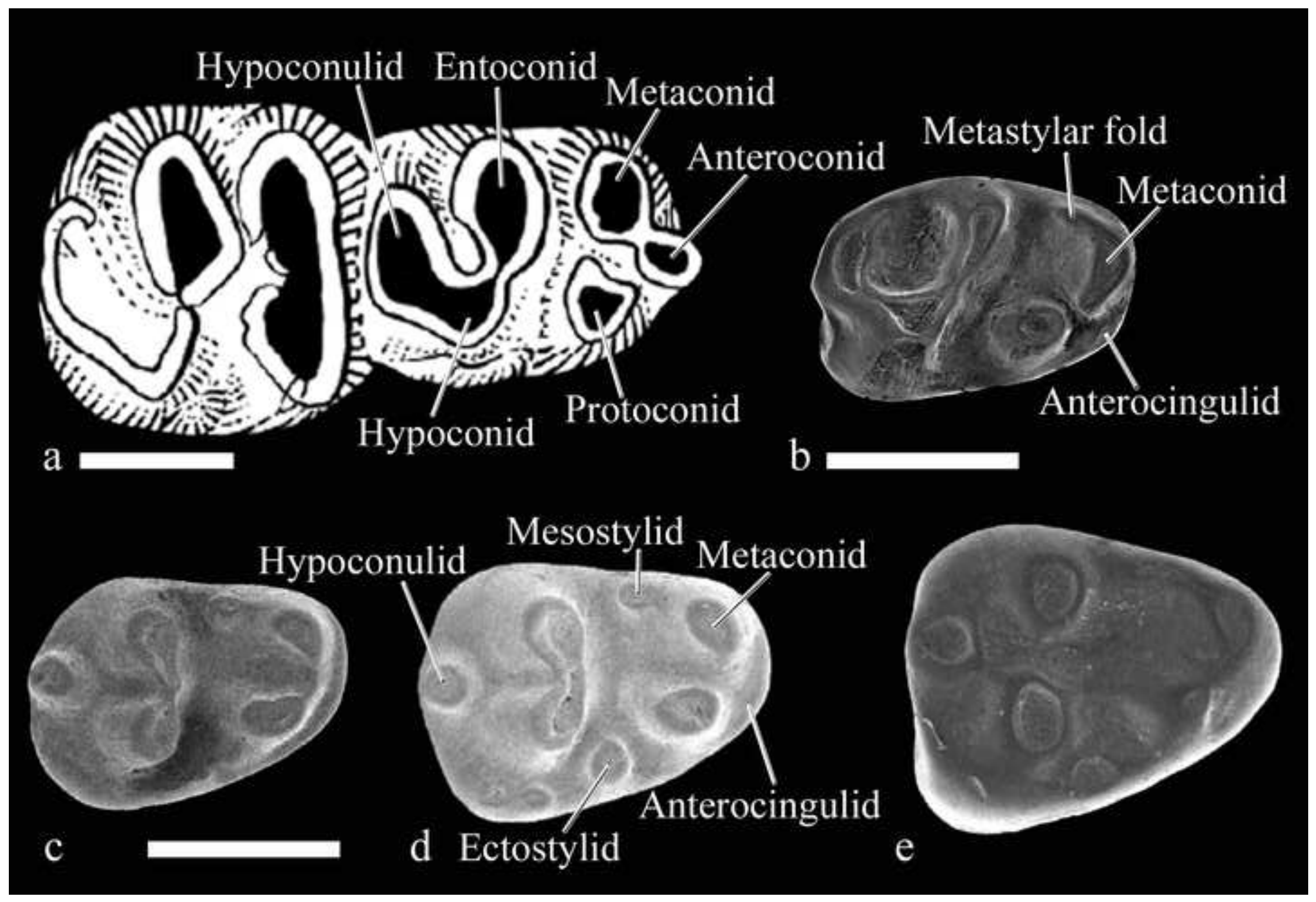




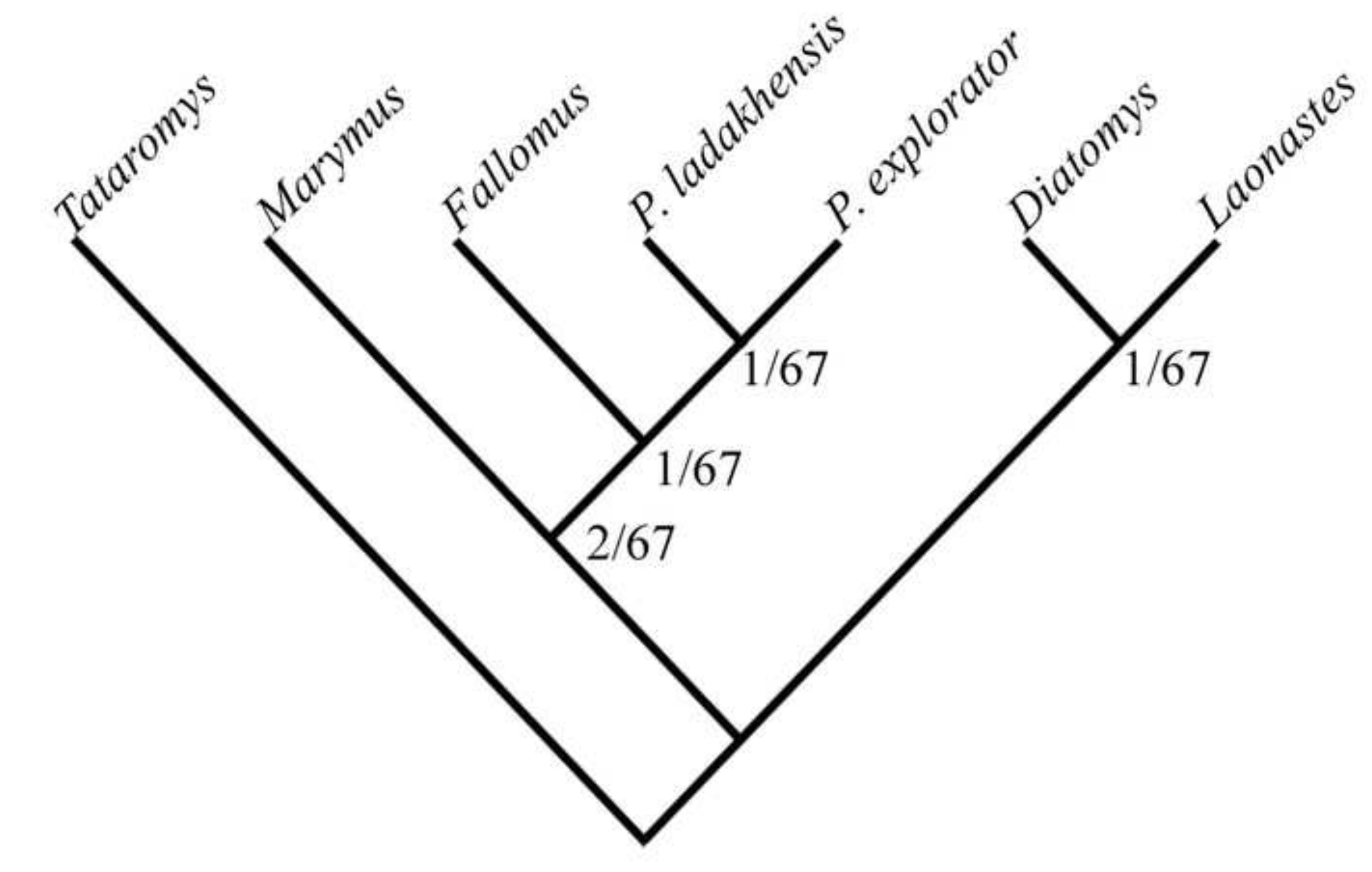

Clck here to download high resolution image 
Supplementary Material
Click here to download Supplementary Material: Supplementary_online_material.doc

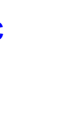

$+2$

(n) 